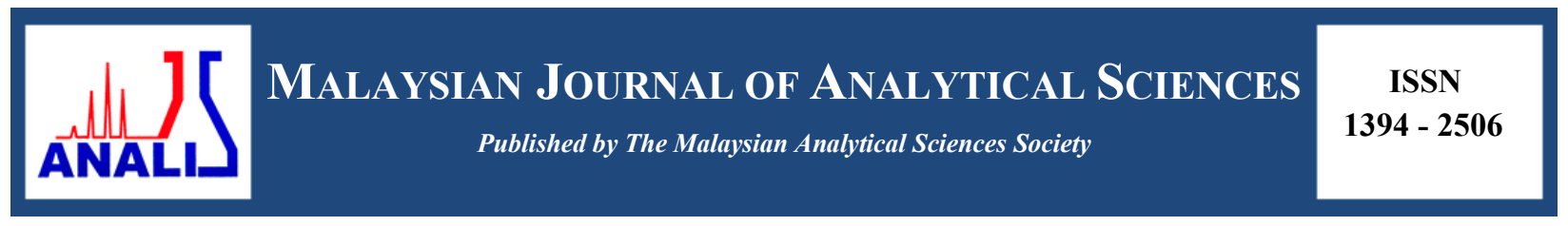

\title{
THE EFFECTS OF DIFFERENT RATIOS OF SONOCHEMICALLY ASSISTED NICKEL OXIDE AND ZIRCONIUM OXIDE CATALYSTS IN SYNGAS PRODUCTION
}

\author{
(Kesan-Kesan Pelbagai Nisbah Pemangkin Nikel Oksida dan Zirkonium Oksida dengan \\ Rawatan Sonokimia Terhadap Penghasilan Singas) \\ Wan Nurdiyana Wan Amarina ${ }^{1,2}$, Wong Yee Ching ${ }^{1,2}$, Taufiq Yap Yun Hin $^{3,4}$ \\ ${ }^{1}$ Faculty of Agro Based Industry \\ ${ }^{2}$ Faculty of Bioengineering and Technology \\ Universiti Malaysia Kelantan, Locked Bag No. 100, 17600 Jeli, Kelantan, Malaysia \\ ${ }^{3}$ Centre of Excellence for Catalysis Science and Technology \\ ${ }^{4}$ Department of Chemistry, Faculty of Science \\ Universiti Putra Malaysia, 43400 UPM Serdang, Selangor, Malaysia \\ *Corresponding author: yeeching@umk.edu.my
}

Received: 28 November 2016; Accepted: 5 February 2017

\begin{abstract}
Heterogeneous catalytic cracking is currently one of the most effective ways for both reducing tar content and enhancing hydrogen $\left(\mathrm{H}_{2}\right)$ content in syngas at relatively low temperature, besides being environmental friendly. Sonochemical treatment has also been shown to lower reaction times with enhanced reaction rate and enables production of particles with high surface area. Two different types of metal oxides, which are Nickel Oxide $(\mathrm{NiO})$ and Zirconium Oxide $\left(\mathrm{ZrO}_{2}\right)$ at combinations of $1: 1$, 1:2 and 2:1 ratios with Zeolite $\mathrm{NaY}$ as the supporter were synthesized via sonochemical treatment. The catalysts were then characterized using X-Ray Diffraction (XRD), Temperature Programmed Reduction in $\mathrm{H}_{2} / \operatorname{Argon}\left(\mathrm{TPR}-\mathrm{H}_{2}\right.$ ), Brunauer-EmmettTeller surface measurement (BET), Scanning Electron Microscopy (SEM) and Transmission Electron Microscopy (TEM). From SEM and TEM analysis, nickel tends to agglomerate and form globular shapes, zirconium forms coral-like branching structure and Zeolite $\mathrm{NaY}$ forms stacks of cubic clumps. The most promising $\mathrm{NiO}$ to $\mathrm{ZrO}_{2}$ ratio for syngas production is $1: 1$ because it removes the most reactive oxygen during hydrogen reduction at $0.83 \times 10^{21}$ atoms $/ \mathrm{g}$, has small crystallite size at $56.90 \mathrm{~nm}$ and has the highest surface area for maximum contact with the reactants at $506.52 \mathrm{~m}^{2} / \mathrm{g}$. Generally, sonochemical treatment also reduces the catalysts crystallite size $(54.83 \mathrm{~nm})$ and increases the catalysts surface area $\left(506.52 \mathrm{~m}^{2} / \mathrm{g}\right)$ and oxygen removal $(0.83$ $\mathrm{x} 10^{21}$ atoms $\left./ \mathrm{g}\right)$ as well as lowers the reduction temperature $(637 \mathrm{~K})$ which is favourable in term of production cost.
\end{abstract}

Keywords: heterogeneous catalysts, nickel oxide, zirconium oxide, zeolite, syngas

Abstrak

Perekahan pemangkin heterogen adalah salah satu cara terkini yang paling efektif untuk mengurangkan kandungan tar dan juga meningkatkan kandungan hidrogen $\left(\mathrm{H}_{2}\right)$ di dalam singas pada suhu rendah, di samping mesra alam sekitar. Rawatan sonokimia juga telah dibuktikan dapat mengurangkan masa tindak balas di samping meningkatkan kadar tindak balas dan membolehkan penghasilan partikel dengan luas permukaan yang tinggi. Dua jenis besi oksida berbeza, iaitu Nikel Oksida (NiO) dan Zirkonium Oksida $\left(\mathrm{ZrO}_{2}\right)$ dalam kombinasi nisbah 1:1, 1:2 dan 2:1 dan Zeolit NaY sebagai penyokong dihasilkan melalui rawatan sonokimia. Katalis - katalis tersebut kemudian dianalis menggunakan pembelauan sinar-X (XRD), Penurunan Suhu Berprogram (TPR-H 2 ), pengukuran permukaan Brunauer-Emmett-Teller (BET), Mikroskop Imbasan Elekron (SEM) dan Mikroskop Elektron Transmisi (TEM). Daripada analisis SEM dan TEM, nikel cenderung untuk bergumpal dan membentuk glob besar, zirkonium membentuk struktur seperti karang bercabang dan Zeolit $\mathrm{NaY}$ membentuk lapisan kubik. Nisbah $\mathrm{NiO}_{\mathrm{kepada}} \mathrm{ZrO}_{2}$ yang paling 
berpotensi adalah 1:1 kerana ia menyingkirkan banyak oksigen yang reaktif semasa reduksi hidrogen pada kadar $0.83 \times 10^{21}$ atom/g, mempunyai saiz kristal yang kecil iaitu $56.90 \mathrm{~nm}$ dan mempunyai luas permukaan yang paling tinggi pada $506.52 \mathrm{~m}^{2} / \mathrm{g}$ untuk kontak maksimum dengan bahan tindak balas. Umumnya rawatan sonokimia juga mengurangkan saiz kristal katalis (54.83 $\mathrm{nm})$ dan meningkatkan luas permukaan pemangkin $\left(506.52 \mathrm{~m}^{2} / \mathrm{g}\right)$ dan juga penyingkiran oksigen $\left(0.83 \times 10^{21}\right.$ atom/g) di samping mengurangkan suhu penurunan $(637 \mathrm{~K})$ di mana ia adalah baik untuk penjimatan kos pengeluaran.

Kata kunci: pemangkin heterogen, nikel oksida, zirkonium oksida, zeolit, singas

\section{Introduction}

The depletion of world petroleum reserves and increased environmental concerns has stimulated the search for the alternative renewable fuels that are capable of fulfilling an increasing energy demand. The biomass fuels represent an abundantly available and renewable energy resource with $\mathrm{CO}_{2}$ neutral impact. It is the only sustainable source of energy and organic carbon for industrial society [1]. Among different processes for their utilization, the biomass gasification is one of the best options in order to optimize the conversion of the chemical energy of the fuel. Instead of using edible biomass (sugars, starches, and vegetable oils) for large scale production of fuels, the development of nonedible biomass (lignocellulosic biomass) permits sustainable and cheaper production of fuels and chemicals without affecting food supplies [1]. Biomass gasification is one of the most promising options for converting lignocellulosic biomass to synthesis gas (syngas), a mixture of $\mathrm{CO}$ and $\mathrm{H}_{2}$, which can be used either as a fuel to produce heat and power or as an intermediate in the production of liquid fuels (e.g. diesel fuel, dimethyl ether) and chemicals (e.g. methanol).

Tar is a complex mixture of condensable organic compounds, which includes single ring to 5-ring aromatic compounds along with other oxygen-containing hydrocarbons and complex polycyclic aromatic hydrocarbons (PAHs), which can foul the equipment and cover the surface of catalysts to slow or stop the reaction [2]. Tars present a number of process challenges, including coking of catalysts and condensation on downstream piping, filters, and other equipment. The tar removal cost is as expensive as the overall process to produce syngas [3]. Tars cause severe operational problems associated with their condensation and polymerization. Tar removal is a critical issue in the development of biomass gasification, especially in the Fischer-Tropsch (F-T) synthesis where those impurities can lower the F-T activity in the bio-syngas catalytic conversion [2]. Moreover, a high $\mathrm{H}_{2} / \mathrm{CO}$ ratio in the gas stream is desirable for F-T synthesis.

Catalytic cracking/reforming is currently one of the most effective ways for both reducing tar content and enhancing $\mathrm{H}_{2}$ content in syngas at relatively low temperature. Recently, conventional homogeneous base catalysts are expected to be replaced in the near future by environmentally friendly heterogeneous base catalysts mainly because of environmental constraints and simplifications in the existing processes. Heterogeneous catalytic is considered as a technology with the highest potential to contribute to the solution of tar decomposition. In addition, the use of a catalyst can enhance the gas yield and promote the reforming reactions of residual hydrocarbons. In heterogeneous reaction, the interaction of methane with metals results in $\mathrm{H}_{2}$ evolution where at temperature above $400 \mathrm{~K}$, dehydrogenation of $\mathrm{CH}_{\mathrm{x}}$ species becomes fast and the elemental carbon is more stable forming stronger bonds with the metal surface [4].

Several catalytic materials have been studied as additives in fluidized-bed reactor in order to achieve in situ catalytic conditioning of the product gas inside the gasifier reactor. Many works on in-bed catalysts consider dolomite $[2,5,6]$, olivine [3,6], nickel [2,3,5-8] and noble metal (NM) based catalysts [4]. A tar conversion rate of $99 \%$ has been achieved by using dolomite and Ni-based catalysts [2]. The catalytic performance of dolomite in tar cracking is directly proportional to the number of surface base sites [3].

Although NMs, such as Ru, Rh, Pd, Pt, and Ir, have been studied extensively for dry reforming reaction, their high cost and limited availability limits their industrial applications [9]. Nickel-based catalyst has been considered as the most suitable due to its fast turnover rates, long-term stability and lower cost [4]. However, the major challenge in many processes involving Ni-based catalyst is deactivation by carbon deposition [2]. Therefore, an effective catalyst that minimizes coke deposition should be developed. Zirconium has been tested as a base catalyst to reform gas containing tarry impurities. Zirconium catalyst works efficiently in decomposing tars, especially heavier 
hydrocarbons. In several tests done by Simell and Kurkela [10], zirconium catalysts provided a tar conversion of 60 to $80 \%$ at a temperature of about $600^{\circ} \mathrm{C}$. Zirconium has also been used as support for Ni-based catalyst for syngas production by dry reforming reaction, which enables direct conversion of natural gas into liquid fuels at remote extraction sites [4].

Metal oxides are constituents of the Earth crust and have been catalyzing different important reactions in chemical evolution. They are good adsorbents and efficient catalysts [11]. They consist of dispersed surface metal oxide species and catalytic active sites supported on high surface area oxides [12]. Mixed metal oxide catalysts are used in heterogeneous catalysis for chemical processes and being further developed for their catalytic performance and durability [13]. Supported metal oxide catalysts have been extensively investigated since 1950s. According to Lee and Wachs [14], the surface metal oxide species of supported metal oxide catalysts control the overall catalytic performance such as activity and selectivity. Zirconium oxide $\left(\mathrm{ZrO}_{2}\right)$ has high thermal stability as a catalyst support. It is proved to be a very good promoter for cobalt catalyst where it enhanced $\mathrm{CO}$ conversion rate and $\mathrm{C} 5+$ selectivity [2]. A study comparing $\mathrm{Ni} / \mathrm{CeO}_{2}, \mathrm{Ni} / \mathrm{ZrO}$, and $\mathrm{Ni} / \mathrm{CeO}_{2}-\mathrm{ZrO}_{2}$ mixed oxide catalysts for methane partial oxidation at $700{ }^{\circ} \mathrm{C}$ showed higher activity and coke resistance on the composite supports as compared to the individual metal oxides [6]. Another study using combination of $\mathrm{Ni}-\mathrm{Ce}-\mathrm{ZrO}_{2}$ catalyst showed high conversions of reactants $(97 \%)$ and provide high resistance to catalyst deactivation, but still requires a high temperature [4].

Catalytic performances are expected to be improved by the optimization of the catalytic filter system and the use of more active in-bed catalysts. In this study, the catalysts used are two different types of metal oxides, which are Nickel Oxide $(\mathrm{NiO})$ and Zirconium Oxide $\left(\mathrm{ZrO}_{2}\right)$ with Zeolite supporter. Zeolites have been added to the conventional F-T system in many studies. They have a shape-selective property that restrains the formation of products that are larger than the size of the zeolite channels and result in lighter hydrocarbons. Zeolites acid site can help with cracking, isomerization and aromatization reactions for F-T products [2]. They are also widely used in heterogeneous catalysis because of their well-defined pore structures and capabilities of extremely high surface area and surface acidity [6].

The catalysts used for this study were synthesized via sonochemical treatment. Sonochemically assisted reactions showed lower reaction times with enhanced reaction rate. It enables production of small and high uniform particles sizes with high surface area, metal dispersion and defects that have been shown to play a crucial role in catalysis [15-20]. The utilization of sonochemical treatment in the synthesis of the catalysts was proven to show significant increase in the catalytic activity, stability and selectivity of catalysts [20].

\section{Preparation of mixed nickel oxide and zirconium oxide catalysts}

Mixture of $\mathrm{NiO}$ and $\mathrm{ZrO}_{2}$ catalysts was synthesized by conventional impregnation /co-precipitation method by mixing $\mathrm{NiO}$ (from $\mathrm{Hmbg}$ ) and $\mathrm{ZrO}_{2}$ (from Acros Organics) at three different $\mathrm{NiO}$ to $\mathrm{ZrO}_{2}$ ratios of 1:1, 1:2 and 2:1 in $100 \mathrm{~mL}$ distilled water. The solutions were then sonicated separately for 30 minutes with $2 \mathrm{~cm}$ diameter Ti-horn, $20 \mathrm{kHz}, 500 \mathrm{~W}$ probe. The temperature was kept constant at $80^{\circ} \mathrm{C}$. The samples were then cooled to room temperature. The resultant solid (mixture of $\mathrm{NiO}$ and $\mathrm{ZrO}_{2}$ ) was then recovered using centrifuge for 5 minutes at $2000 \mathrm{rpm}$ [21]. It was then subsequently washed with distilled water followed by washing with acetone to remove the by-products [22] before oven dried overnight at $105^{\circ} \mathrm{C}$ for 12 hours according to Tao et al. [23].

\section{Preparation of Zeolite NaY supporter}

The supporter used was Zeolite Y sodium (Zeolite NaY), procured from Alfa Aesar. Table 1 showed its mole ratio and surface area.

Zeolite $\mathrm{NaY}$ was first treated with sonochemical treatment and the resultant solid was recovered using centrifuge before oven dried overnight at $105{ }^{\circ} \mathrm{C}$. The synthesized mixture of $\mathrm{NiO}$ and $\mathrm{ZrO}_{2}$ were then added with Zeolite at a loading of $10 \mathrm{~g}$ equally, in $100 \mathrm{~mL}$ distilled water. The mixture was then stirred on a hot plate with a magnetic stirrer for one hour. The solid was again recovered using centrifuge technique and subsequently washed with distilled water followed with acetone then oven dried overnight at $105^{\circ} \mathrm{C}$ for 12 hours [23]. The catalysts mixtures were then calcined in air at $500{ }^{\circ} \mathrm{C}$ for 4 hours, yielding a homogeneous catalyst powder, according to Klimova et al. [24] 
and Maciel et al. [25]. Calcining the synthesized catalysts powders also removes structure directing agents and other organic substances present in them [26].

Table 1. Mole ratio and surface area of Zeolite $\mathrm{NaY}$

\begin{tabular}{lcc}
\hline Zeolite NaY Characterization & $\mathbf{S i O}_{\mathbf{2}}$ & $\mathbf{A l}_{\mathbf{2}} \mathbf{O}_{\mathbf{3}}$ \\
\hline Mole ratio & 5.1 & 1 \\
Surface area $\left(\mathrm{m}^{2} / \mathrm{g}\right)$ & 900 & 900 \\
\hline
\end{tabular}

\section{Catalyst characterization}

The catalysts were then characterized through a series of analysis as follows. X-ray diffraction (XRD) analysis was carried out using Shimadzu diffractometer model XRD 6000 at range $2 \Theta$ from $5^{\circ}$ to $80^{\circ}$ in continuous scanning at $2^{\circ}$ per minute and sampling pitch of $0.02^{\circ}$. Hydrogen temperature programmed reduction analysis $\left(\mathrm{H}_{2}-\mathrm{TPR}\right)$ was performed using Thermo Fisher Scientific TPDRO 1100 apparatus that was equipped with a thermal conductivity detector (TCD). The total surface areas of the catalysts were then measured using Thermo Electron Sorptomatic 1990 and Quantachrome AS1Win ${ }^{\mathrm{TM}}$ Automated Gas Sorption Data Acquisition and Reduction utilizing BrunauerEmmett-Teller (BET) method. The catalyst samples were degassed at $300{ }^{\circ} \mathrm{C}$ for 12 hours. Electron microscopy technique was used to obtain the information on the morphology and size of the catalyst samples by using LEO 1455 Variable Pressure scanning electron microscope (SEM). The particle sizes of the samples were examined using Hitachi H-7100 energy filter transmission electron microscope (TEM).

\section{X-Ray diffraction analysis}

\section{Results and Discussion}

X'Pert HighScore software from PANalytical B. V. was used to analyze the XRD data. From the XRD data of all samples, the presence of $\mathrm{NiO}$ phase appeared consistently at $2 \theta=37.3^{\circ}, 43.4^{\circ}, 62.8^{\circ}$ and $75.4^{\circ}$ (JCPDS File No. 00-022-1189) but the peak intensities are very low. This might be due to high metal dispersion of $\mathrm{NiO}$ on the surface of Zeolite $\mathrm{NaY}$ due to the effect of sonochemical treatment in improving particles size distribution The presence of $\mathrm{ZrO}_{2}$ phase appeared at multiple degrees $=24^{\circ}, 24.3^{\circ}, 28.4^{\circ}, 31.7^{\circ}, 34.4^{\circ}, 35.6^{\circ}, 40.9^{\circ}, 49.4^{\circ}, 50.3^{\circ}$, $50.8^{\circ}, 54.2^{\circ}, 55.5^{\circ}, 58.6^{\circ}$ and $62.2^{\circ}$ (JCPDS File No. 00-013-0307). While Zeolite NaY showed multiple peaks at $2 \Theta=6.4^{\circ}, 10.5^{\circ}, 12.2^{\circ}, 15.9^{\circ}, 19.0^{\circ}, 20.6^{\circ}, 23.0^{\circ}, 24.0^{\circ}, 27.3^{\circ}, 29.9^{\circ}, 31.1^{\circ}, 31.7^{\circ}, 34.4^{\circ}, 40.9^{\circ}, 49.4^{\circ}$ and $54.2^{\circ}$ (JCPDS File No. 00-038-0239). Some of the peaks of $\mathrm{ZrO}_{2}$ and Zeolite NaY seem to overlap with each other and it is quite difficult to distinguish the peaks between the two.

Based from the peak intensities shown in Figure 1, the sonochemically treated catalysts with $\mathrm{NiO}: \mathrm{ZrO}_{2}$ ratio of 1:1 shows the lowest peak intensities followed by catalysts ratio 2:1 and 1:2. It seems that equal amount of $\mathrm{NiO}$ and $\mathrm{ZrO}_{2}$ contributes to higher dispersion of metal oxides on Zeolite's surface compared to the unequal amounts of NiO and $\mathrm{ZrO}_{2}$. Catalysts ratio 1:2 shows the highest peak intensities where $\mathrm{ZrO}_{2}$ is double the amount of $\mathrm{NiO}$. Since the peaks of $\mathrm{ZrO}_{2}$ are more prominent than $\mathrm{NiO}$, it can be said that $\mathrm{ZrO}_{2}$ is not as well dispersed as $\mathrm{NiO}$ on the surface of Zeolite NaY supporter.

Zeolite $\mathrm{NaY}$ generally has the highest crystallinity and more defined structures compared to $\mathrm{NiO}$ and $\mathrm{ZrO}_{2}$. It is identified to possess cubic crystal system. Its particle size is also the largest compared to $\mathrm{NiO}$ and $\mathrm{ZrO}_{2}$ (average of 201 to $493 \mathrm{~nm}$ ). The size of crystallite can be estimated from the XRD data as shown in Table 2, using Scherrer equation in equation 1 [27],

$$
\mathrm{L}=\mathrm{K} \lambda / \beta \cdot \cos \Theta
$$

where $\mathrm{L}=$ average crystallite size, $\mathrm{K}=$ constant which is normally taken as $0.9, \lambda=\mathrm{X}$-ray wavelength, $\beta=$ peak width of the diffraction profile at half maximum height and $\Theta$ can be either in degrees or radians. 
Based from Table 2, catalyst ratio 2:1 showed the smallest crystallite size average of $54.83 \mathrm{~nm}$ compared to other catalysts with different ratios. This is to be expected since the TEM analysis images also show that Ni has the smallest particle size (average of 6 to $12 \mathrm{~nm}$ ) and that the high amount of $\mathrm{NiO}$ means it is well dispersed on the surface of the catalyst, thus contributing to smaller crystallite size. However, the crystallite size of catalyst 2:1 is not significantly different than catalyst ratio 1:1. While catalyst ratio 1:2 shows the biggest crystallite size due to higher amount of $\mathrm{ZrO}_{2}$.

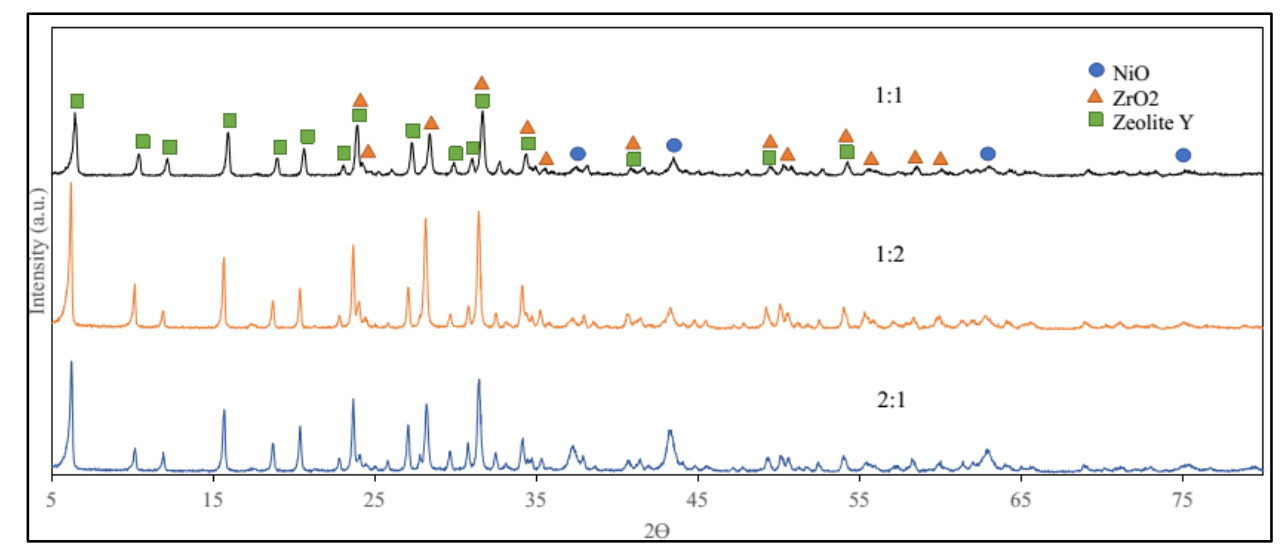

Figure 1. XRD patterns of $\mathrm{NiO}: \mathrm{ZrO}_{2}$ catalysts ratio of 1:1, 1:2 and 2:1 treated with sonochemical treatment for 30 minutes

Table 2. Crystallite size average from XRD data (nm)

\begin{tabular}{cc}
\hline Catalyst & $\begin{array}{c}\text { Crystallite Size Average } \\
(\mathbf{n m})\end{array}$ \\
\hline $1: 1$ & 56.90 \\
$1: 2$ & 62.51 \\
$2: 1$ & 54.83 \\
\hline
\end{tabular}

Temperature programmed reduction (TPR in $\mathrm{H}_{2} / \mathrm{Ar}$ )

All catalyst samples produced a single reduction peak at temperature ranging from $637 \mathrm{~K}$ to $657 \mathrm{~K}$ as shown in Figure 2 and Table 3.

As can be seen in Table 3, catalyst ratio 1:1 removed the highest amount of oxygen at $0.83 \times 10^{21}$ atoms $/ \mathrm{g}$ followed by catalysts ratio $2: 1$ and $1: 2$. From the data, it is shown that catalyst ratio $1: 1$ is the most efficient reactive oxygen removal while catalyst ratio $1: 2$ is the least efficient with reactive oxygen removal at $0.48 \times 10^{21}$ atoms $/ \mathrm{g}$. This is also in agreement with the XRD data discussed earlier where catalyst ratio 1:1 with equal distribution of $\mathrm{NiO}$ and $\mathrm{ZrO}_{2}$ is well dispersed with small crystallite size. However, catalyst ratio $1: 2$ and $2: 1$ have lower $\mathrm{T}_{\max }$ at $637 \mathrm{~K}$ and $653 \mathrm{~K}$ respectively compared to catalyst ratio $1: 1$ at $657 \mathrm{~K}$. Despite the $20 \mathrm{~K} \mathrm{~T}_{\max }$ difference between catalysts ratio $1: 1$ and 1:2, catalyst ratio $1: 1$ has almost double the amount of reactive oxygen removed compared to catalyst ratio $1: 2$. 


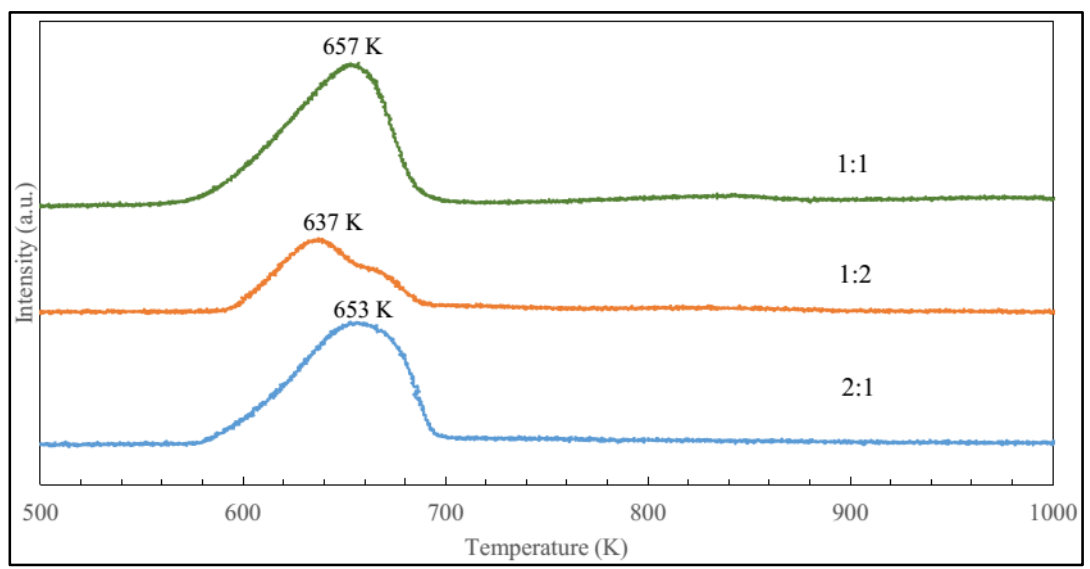

Figure 2. Temperature programmed reduction profiles for $\mathrm{NiO}: \mathrm{ZrO}_{2}$ ratio 1:1, 1:2 and 2:1

Table 3. Total amount of oxygen removed from the catalysts by reduction in $\mathrm{H}_{2} / \mathrm{Ar}$

\begin{tabular}{cccc}
\hline Catalyst & $\mathbf{T}_{\max }(\mathbf{K})$ & $\begin{array}{c}\mathbf{H}_{2} \text { gas adsorbed } \\
\left(\mathbf{x 1 0 ^ { - 3 }} \mathbf{~ m o l} / \mathbf{g}\right)\end{array}$ & $\begin{array}{c}\text { Total } \mathbf{O}_{2} \text { removed } \\
\left(\mathbf{x 1 0 ^ { \mathbf { 2 1 } }} \text { atoms/g) }\right.\end{array}$ \\
\hline $1: 1$ & 657 & 1.37 & 0.83 \\
$1: 2$ & 637 & 0.79 & 0.48 \\
$2: 1$ & 653 & 1.21 & 0.73 \\
\hline
\end{tabular}

\section{Scanning electron microscope}

In all samples, $\mathrm{NiO}$ tends to agglomerate into large globular shape while Zeolite $\mathrm{NaY}$ forms stacks of cubic shaped clumps and mostly spread out trough out the entire sample. Generally $\mathrm{ZrO}_{2}$ forms the smallest structures among the other two catalysts. It was seen to be in cylindrical form in coral-like branching structure distributed throughout the sample. Figure 3 shows large globular clumps of $\mathrm{NiO}$ surrounded by Zeolite $\mathrm{NaY}$ and some smaller coral-like $\mathrm{ZrO}_{2}$ clumps can be seen around it.
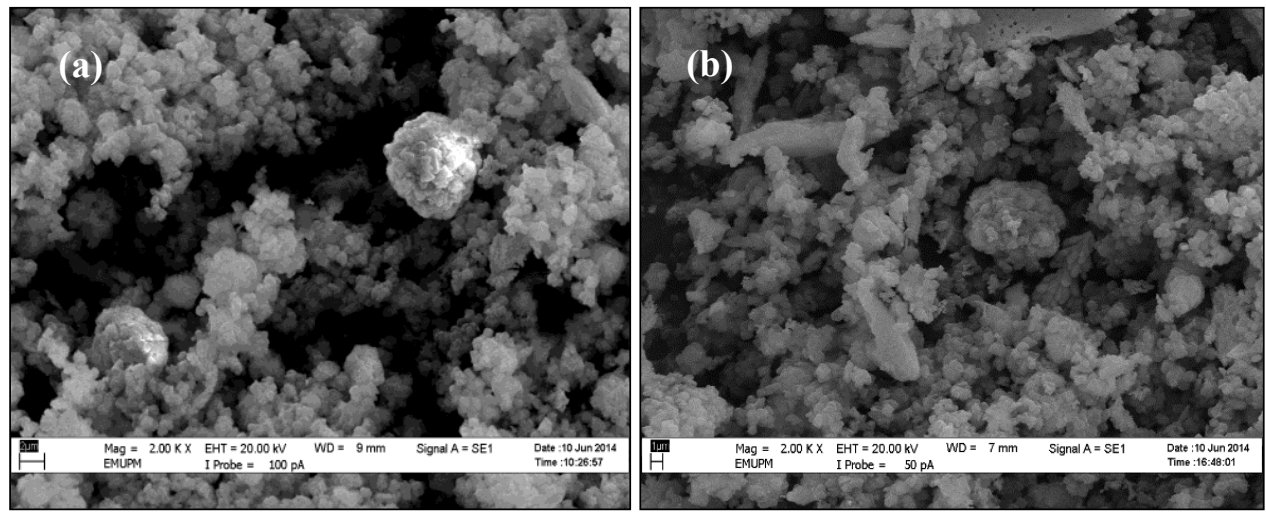


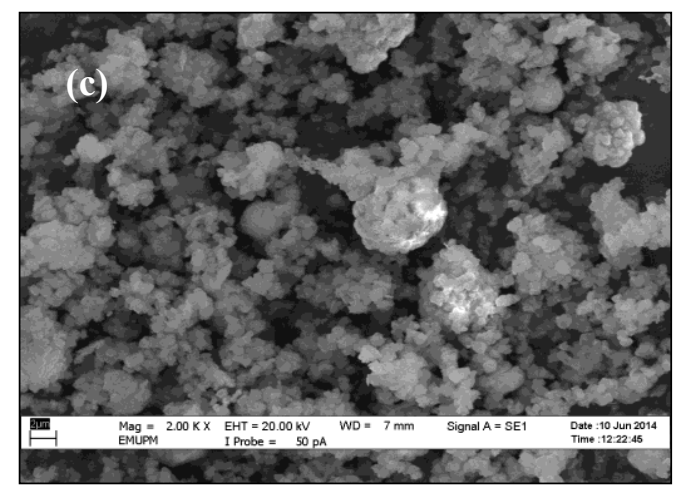

Figure 3. SEM micrograph of sample (a) 1:1, (b) 1:2, and (c) 2:1 at magnification 2000x

Catalyst ratio 1:1 shows $\mathrm{NiO}$ agglomerated globular clumps with $\mathrm{ZrO}_{2}$ smaller structures are equally distributed on the surface of Zeolite $\mathrm{NaY}$ while catalyst ratio 1:2 shows more and bigger structures of $\mathrm{ZrO}_{2}$ on the surface of the catalyst. Globular clumps of $\mathrm{NiO}$ are more apparent in catalyst ratio 2:1, as can be seen in Figure 3 .

\section{Transmission electron microscope}

Figure 4 shows agglomerated $\mathrm{NiO}$ particles with sizes ranging from 6 to $12 \mathrm{~nm}$ in catalyst ratio 1:1. From the same sample, $\mathrm{ZrO}_{2}$ forms coral-like branching structures with diameters ranging from 74 to $94 \mathrm{~nm}$ while crystal-like Zeolite NaY stacks up on each other with diameters ranging from 201 to $493 \mathrm{~nm}$. TEM images shows that $\mathrm{ZrO}_{2}$ average particle size is larger than $\mathrm{NiO}$ and this is in agreement with XRD results where catalysts ratio $1: 2$ also has the highest peak intensities where $\mathrm{ZrO}_{2}$ is double the amount of NiO. Since the peaks of $\mathrm{ZrO}_{2}$ are more prominent than $\mathrm{NiO}$, it can be said that $\mathrm{ZrO}_{2}$ is not as well dispersed as $\mathrm{NiO}$ on the surface of Zeolite $\mathrm{NaY}$ supporter due to its larger particle size and its branching structures.
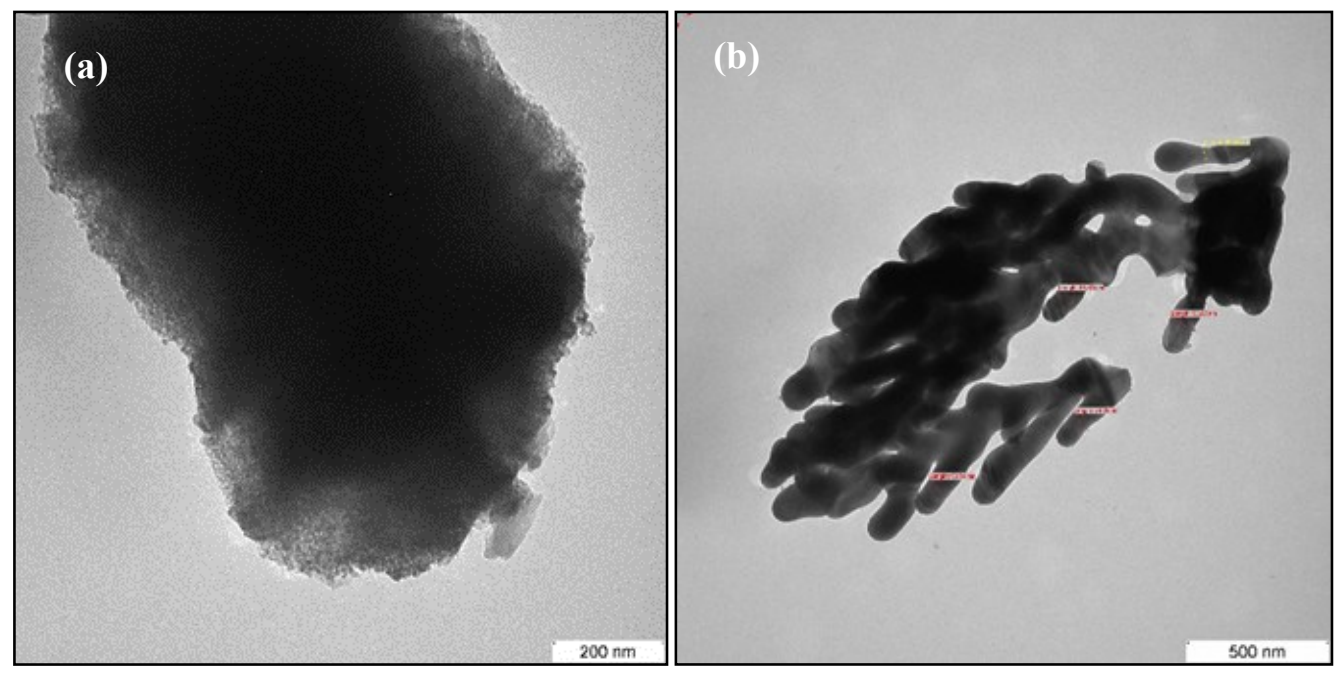


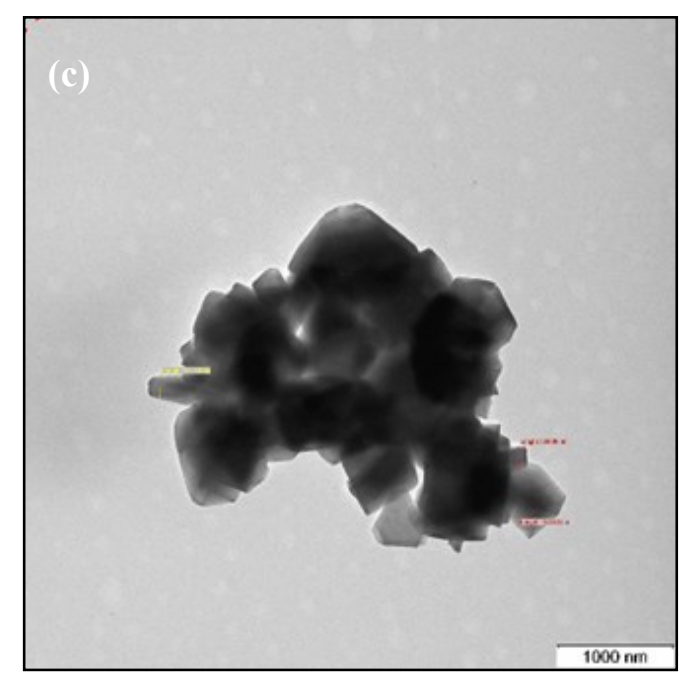

Figure 4. TEM micrograph of catalyst ratio 1:1 of (a) $\mathrm{NiO}$ at magnification $100000 \mathrm{x}$, (b) $\mathrm{ZrO}_{2}$ at magnification $50000 x$, and (c) Zeolite at magnification $20000 x$

\section{BET surface area measurement}

Based from Table 4, catalyst with the highest surface area is catalyst ratio $1: 1$ with surface area of $506.52 \mathrm{~m}^{2} / \mathrm{g}$ and the lowest surface area is catalyst ratio 1:2 with surface area of $399.88 \mathrm{~m}^{2} / \mathrm{g}$. This is in agreement with the XRD and TPR $-\mathrm{H}_{2}$ data where catalyst ratio $1: 1$ has well dispersed metal oxides with average crystallite size of $56.90 \mathrm{~nm}$ and the highest reactive oxygen removal at $0.83 \times 10^{21}$ atoms/g compared to catalysts ratio $1: 2$ and 2:1.

While catalyst ratio 1:2, with its higher amount of $\mathrm{ZrO}_{2}$ on the surface of Zeolite $\mathrm{NaY}$ has reduced the surface area of the catalyst $\left(399.88 \mathrm{~m}^{2} / \mathrm{g}\right)$ as well as reduced contact with the active sites thus contributing to low removal of reactive oxygen as presented in previous TPR- $\mathrm{H}_{2}$ section discussion.

The presence of Zeolite $\mathrm{NaY}$ supporter and $\mathrm{ZrO}_{2}$ in catalysts was reported by Derekaya and Yasar [28] to give higher surface area compared to the catalysts without their presence. Zeolite $\mathrm{NaY}$ also has high surface area (900 $\mathrm{m}^{2} / \mathrm{g}$ ) and well dispersed pore structure. $\mathrm{ZrO}_{2}$ was also implied to act as a surface area agent. However, higher ratio of $\mathrm{ZrO}_{2}$ to $\mathrm{NiO}$ is proven to significantly reduce the surface area of the catalysts.

There is also a huge discrepancy between pure Zeolite NaY surface area $\left(900 \mathrm{~m}^{2} / \mathrm{g}\right)$ and treated Zeolite NaY surface area. The drying and calcination of catalyst could also possibly affect the total surface area. This also means that both $\mathrm{NiO}$ and $\mathrm{ZrO}_{2}$ loading on Zeolite $\mathrm{NaY}$ significantly reduced the surface area of Zeolite NaY. This might be due to the effects of sonication treatment which caused the agglomeration of active metal $\mathrm{Ni}$ on the surface of Zeolite $\mathrm{NaY}$ where it could lead to blockage of pores and reduces the overall surface area of Zeolite NaY [17].

Table 4. Specific BET surface area of $\mathrm{NiO}: \mathrm{ZrO}_{2}$ catalysts

\begin{tabular}{cc}
\hline Catalyst & $\begin{array}{c}\text { Surface Area } \\
\left(\mathbf{m}^{2} / \mathbf{g}\right)\end{array}$ \\
\hline $1: 1$ & 506.52 \\
$1: 2$ & 399.88 \\
$2: 1$ & 436.37 \\
\hline
\end{tabular}


A summary of comparisons between catalysts ratio 1:1, 1:2 and 2:1 is shown in Table 5 .

Table 5. Comparisons of properties between catalysts with different ratio

\begin{tabular}{|c|c|c|c|c|c|}
\hline Catalyst & $\begin{array}{l}\text { Average Crystallite } \\
\text { Size (nm) }\end{array}$ & $\begin{array}{l}\mathbf{T}_{\max } \\
(\mathbf{K})\end{array}$ & $\begin{array}{c}\mathrm{H}_{2} \text { Gas Adsorbed } \\
\left(\times 10^{-3} \mathrm{~mol} / \mathrm{g}\right)\end{array}$ & $\begin{array}{c}\text { Total } O_{2} \text { Removed } \\
\left(\times 10^{21} \text { atoms } / g\right)\end{array}$ & $\begin{array}{l}\text { Surface area } \\
\left(\mathrm{m}^{2} / \mathrm{g}\right)\end{array}$ \\
\hline $1: 1$ & 56.90 & 657 & 1.37 & 0.83 & 506.52 \\
\hline $1: 2$ & 62.51 & 637 & 0.79 & 0.48 & 399.88 \\
\hline $2: 1$ & 54.83 & 653 & 1.21 & 0.73 & 436.37 \\
\hline
\end{tabular}

\section{Conclusion}

The catalysts studied, which are $\mathrm{NiO}$ and $\mathrm{ZrO}_{2}$ with Zeolite $\mathrm{NaY}$ as supporter will help in the study of catalytic cracking/ reforming mechanisms in good quality and cleaner syngas production. However the results are not conclusive yet since syngas evaluation using Temperature Programmed Gasification (TPG) has not been done yet. The results from TPG analysis will determine the performance of the catalysts and will relate with the catalysts characterization data. For now, it can be said that the most promising $\mathrm{NiO}$ to $\mathrm{ZrO}_{2}$ catalyst ratio is ratio 1:1 because of the well dispersion of mixed metal oxides on the catalyst surface with small average crystallite size of $56.90 \mathrm{~nm}$, removal of reactive oxygen at the highest rate at $0.83 \times 10^{21}$ atoms $/ g$ as well as possessing the highest surface area at $506.52 \mathrm{~m}^{2} / \mathrm{g}$. Equal distribution of mixed metal oxides on the surface of Zeolite NaY supporter produces favourable characteristics for the production of quality syngas. Higher amount of $\mathrm{ZrO}_{2}$ however causes blockage of the pores, thus reduces the catalyst surface area because of its tendencies to agglomerate and form large branching structures, which produces catalyst of poorer profile compared to catalysts ratio 1:1 and 2:1. From SEM and TEM analysis, $\mathrm{NiO}$ tends to agglomerate and form sizable globular shapes, $\mathrm{ZrO}_{2}$ forms coral-like branching structure and Zeolite $\mathrm{NaY}$ forms stacks of cubic clumps. From the catalysts characterization data and analysis obtained, catalysts with $\mathrm{NiO}: \mathrm{ZrO}_{2}$ ratio of 1:1 seems to be a promising catalyst for producing rich syngas with higher catalytic activity and reaction.

\section{Acknowledgement}

This work was supported by Research Grant R/FRAGS/A07.00/00457A/003/2014/000180 from the Ministry of Higher Education, Malaysia.

\section{References}

1. Serrano-Ruiz, J. C., West, R. M. and Dumesic, J. A. (2010). Catalytic conversion of renewable biomass resources to fuels and chemicals. Annual Review of Chemical and Biological Engineering, 1: 79 - 100.

2. Hu, J., Yu, F. and Lu, Y. (2012). Application of Fischer-Tropsch synthesis in biomass to liquid conversion. Catalysis, 2(2): $303-326$.

3. Rownaghi, A. A. and Huhnke, R. L. (2013). Producing hydrogen-rich gases by steam reforming of syngas tar over $\mathrm{CaO} / \mathrm{MgO} / \mathrm{NiO}$ catalysts. American Chemical Society Sustainable Chemistry \& Engineering, 1: 80 - 86.

4. Havran, V., Dudukovi, M. P. and Lo, C. S. (2011). Conversion of methane and carbon dioxide to higher value products. Industrial \& Engineering Chemistry Research, 50: 7089 - 7100.

5. Mohammed, M. A. A., Salmiaton, A., Wan Azlina, W. A. K. G., Mohamad Amran, M. S., Omar, R., Taufiq-Yap, Y. H. and Ahmadun, F. R. (2012). Catalytic gasification of empty fruit bunch for enhanced production of hydrogen rich fuel gas. Pertanika Journal of Science \& Technology, 20(1): 139 - 149.

6. Yung, M. M., Jablonski, W. S. and Magrini-Bair, K. A. (2009). Review of catalytic conditioning of biomassderived syngas. Energy \& Fuels, 23: $1874-1887$.

7. Deghedi, L., Basset, J. -M., Candy, J. -P., Dalmon, J. -A., Dubreuil, A-C. and Fischer, L. (2009). Nanosized bimetallic Ni-Sn and Ni-Zr catalysts prepared by SOMC/M route: Characterization and catalytic properties in styrene selective hydrogenation. Chemical Engineering Transaction, 17: 31 - 36. 
8. Nakayama, O., Ikenaga, N., Miyake, T., Yagasaki, E. and Suzuki, T. (2010). Production of synthesis gas from methane using lattice oxygen of $\mathrm{NiO}-\mathrm{Cr}_{2} \mathrm{O}_{3}-\mathrm{MgO}$ complex oxide. Industrial \& Engineering Chemistry Research, 49: $526-534$.

9. Moon, D. J. (2008). Hydrogen production by catalytic reforming of gaseous hydrocarbons (methane \& LPG). Catalysis Surveys from Asia, 12(3): 188 - 202.

10. Simell, P. and Kurkela, E. (2007). International Publication No. WO 2007/116121 A1. Helsinki, Finland: World Intellectual Property Organization (WIPO).

11. Kamaluddin. (2013). Role of metal oxides in chemical evolution. In S. K. Chakrabarti, K. Acharyya, \& A. Das (Eds.), AIP Conference Proceedings, 1543 (1): 90 - 98.

12. Wachs, I. E. and Kim, T. (2009). Oxidation reactions over supported metal oxide catalysts: Molecular/ electronic structure-activity/selectivity relationships. In Jackson, S. D. and Hargreaves, Justin S. J. (Eds). Metal oxide catalysis. WILEY-VCH Verlag GmbH \& Co. KGaA. Weinheim, Germany: pp. $487-488$.

13. Lee, D. W. and Yoo, B. R. (2014). Advance metal oxide (supoorted) catalysts: Synthesis and applications. Journal of Industrial and Engineering Chemistry, 20(6): 3947 - 3959.

14. Lee, E. L. and Wachs, I. E. (2009). Use of oxide ligands in designing catalytic active sites. In Ozkan, U. S. (Ed). Design of heterogeneous catalysts: new approaches based on synthesis, characterization and modeling. WILEY-VCH Verlag GmbH \& Co. KGaA. Weinheim, Germany.

15. Gole, V. L. and Gogate, P. R. (2012). A review on intensification of synthesis of biodiesel from sustainable feed stock using sonochemical reactors. Chemical Engineering and Processing, 53: 1 - 9.

16. Saminda, D., King'ondu, C. K., Pedrick, W., Lakshitha, P. and Suib, S. L. (2012). Direct sonochemical synthesis of manganese octahedral molecular sieve (OMS-2) nanomaterials using cosolvent systems, their characterization, and catalytic applications. Chemistry of Materials, 24(4): $705-712$.

17. Sharifi, M., Haghighi, M. and Abdollahifar, M. (2015). Sono-dispersion of bimetallic Ni-Co over Zeolite Y used in conversion of greenhouse gases $\mathrm{CH}_{4} / \mathrm{CO}_{2}$ to high valued syngas. Journal of Natural Gas Science and Engineering, 23: $547-558$.

18. Zhong, Y. L. and Bernasek, S. L. (2011). Mild and efficient functionalization of hydrogen-terminated Si(III) via sonochemical activated hydrosilylation. Journal of the American Chemical Society, 133: 8118-8121.

19. Chavan, V. P. and Gogate, P. R. (2011). Intensification of synthesis of cumene hydroperoxide using sonochemical reactors. Industrial \& Engineering Chemistry Research. 50(22): 12433 - 12438.

20. Zhang, X., Jiang, W., Gong, X. and Zhang, Z. (2010). Sonochemical synthesis and characterization of magnetic separable of $\mathrm{Fe}_{3} \mathrm{O}_{4} / \mathrm{Ag}$ composites and its catalytic properties. Journal of Alloys and Compounds, 508(2): 400 405.

21. Taufiq-Yap, Y. H., Joshua Hoh, J. R. and Wong, Y. C. (2011). Synthesis of nanostructured vanadium phosphate catalysts using sonochemical route for partial oxidation of n-butane. Journal of Applied Sciences, 11(13): 2370 -2375 .

22. Meybodi, S. M., Hosseini, S. A., Rezaee, M., Sadrnezhaad, S. K. and Mohammadyani, D. (2012). Synthesis of wide band gap nanocrystalline $\mathrm{NiO}$ powder via a sonochemical method. Ultrasonics Sonochemistry, 19: 841 845 .

23. Tao, J., Zhao, L., Dong, C., Lu, Q., Du, X. and Dahlquist, E. (2013). Catalytic steam reforming of toluene as a model compound of biomass gasification tar using Ni-CeO 2 /SBA-15 catalysts. Energies, 6: $3284-3296$.

24. Klimova, T., Pena, L., Lizama, L., Salcedo, C. and Gutierrez, Y. (2009). Modification of activity and selectivity of NiMo/SBa-15 HDS catalysts by grafting of different metal oxides on the support surface. Industrial \& Engineering Chemistry Research, 48: 1126-1133.

25. Maciel, C. G., Silva, T. D., Assaf, E. M. and Assaf, J. M. (2013). Hydrogen production and purification from the water-gas shift reaction on $\mathrm{CuO} / \mathrm{CeO}_{2}-\mathrm{TiO}_{2}$ Catalysts. Applied Energy, 112: $52-59$.

26. Pal, P., Das, J. K., Das, N. and Bandyopadhyay, S. (2013). Synthesis of NaP Zeolite at room temperature and short crystallization time by sonochemical method. Ultrasonics Sonochemistry, 20: $314-321$.

27. Monshi, A., Foroughi, M. R. and Monshi, M. R. (2012). Modified Scherrer equation to estimate more accurately nano-crystallite size using XRD. World Journal of Nano Science and Engineering, 2: 154-160.

28. Derekaya, F. B. and Yasar, G. (2011). The CO methanation over NaY-Zeolite supported Ni/ $/ \mathrm{Co}_{3} \mathrm{O}_{4}, \mathrm{Ni} / \mathrm{ZrO}_{2}$, $\mathrm{Co}_{3} \mathrm{O}_{4} / \mathrm{ZrO}_{2}$ and $\mathrm{Ni} / \mathrm{Co}_{3} \mathrm{O}_{4} / \mathrm{ZrO}_{2}$ catalysts. Catalysis Communications, 13: $73-77$. 